\title{
FACTORS DETERMINING THE EFFECTIVENESS OF CONSERVATIVE TREATMENT IN PATIENTS WITH CARPAL TUNNEL SYNDROME
}

\author{
JOLANTA ZWOLIŃSKA ${ }^{1,2}$ and ANDRZEJ KWOLEK ${ }^{1}$ \\ ${ }^{1}$ University of Rzeszów, Rzeszów, Poland \\ Faculty of Medicine, Institute of Physiotherapy \\ ${ }^{2}$ St. Hedvig Clinical Provincial Hospital No. 2, Rzeszów, Poland
}

\begin{abstract}
Objectives: The study aims to assess selected factors contributing to the long-term effects of the conservative treatment of carpal tunnel syndrome (CTS). Material and Methods: Forty-nine individuals diagnosed with CTS were enrolled in the study. The symptoms resulted from occupational hand overuse in 37 patients. The assessment involved 78 hands before the therapy (study 1) and 1 year after the end of the therapy (study 2). The clinical symptoms assessed included: pain, numbness, tingling, morning stiffness, vegetative disorders and difficulties in activities of daily living $(\mathrm{ADL})$. The range of motion $(\mathrm{ROM})$ in the hand joints and the pressure generated during the cylindrical grip were measured. Phalen's tests, an electrodiagnostic test and a 2-point discrimination study were performed. Results: A significant reduction of symptoms and improvement in tested parameters were found in study 2 . The largest ROM in the hand, the lowest level of pain and the largest reduction in the frequency of daytime tingling were found in the oldest patients in study 2. In subjects with better initial electrodiagnostic test results, a significant reduction in daytime numbness and daytime tingling was obtained. In individuals previously subjected to conservative therapy, a significant improvement in the ROM of the hand and a better quality of sensation were noted in study 2 . A higher level of pain, a lower reduction in the frequency of daytime tingling, and a smaller improvement in ADL capacity were noted in individuals who overused their hands at work after the therapy. Conclusions: The effects of conservative CTS treatment after 1 year, expressed as the reduction of subjective symptoms, were independent of the patient's age. A worse initial electrodiagnostic test result is a predictor of less favorable therapy results. Hand overuse during occupational activity may negatively affect the effects of conservative treatment in individuals with CTS. A change in the nature of occupational activity positively influenced the long-term maintenance of the effects of conservative treatment. Int J Occup Med Environ Health. 2019;32(2):197-215
\end{abstract}

Key words:

occupational diseases, carpal tunnel syndrome, neuropathy, repetitive overuse, physical therapy techniques, sonotherapy

\section{INTRODUCTION}

Carpal tunnel syndrome (CTS) is a serious social problem. Its most common type is idiopathic CTS [1,2]. A high incidence of the syndrome is observed in highly developed countries among professionally active individuals improperly performing workplace activities which require prolonged or repeated bending/straightening of the radiocarpal joint, the use of considerable force or manual vibra- tion tools [3,4]. The risk of CTS is the greatest when these elements are present [5,6]. Palmer et al. [7] distinguished 3 types of occupational activity that predisposed to CTS incidence, i.e., the use of vibratory tools, assembly work, and food processing and packaging. According to reviews by Thomsen [8], Mediouni [9] and Van Rijn [10], the incidence of CTS may be partly related to the use of computer

Funding: this study was supported by the University of Rzeszów (statutory research of the Institute of Physiotherapy No. 507).

Received: December 27, 2017. Accepted: June 15, 2018.

Corresponding author: Jolanta Zwolińska, University of Rzeszów, Faculty of Medicine, Institute of Physiotherapy, Malczewskiego 2/10, 35-114 Rzeszów, Poland (e-mail: jolantazwolinska@op.pl). 
keyboard and mouse devices; however, this relationship has not been explicitly confirmed.

In turn, Pullopdissakul et al. did not confirm any connections between the repetitive motion of the limb (hand) and the incidence of CTS and other upper extremity musculoskeletal disorders (UEMSD) [11]. Other non-occupational risk factors of CTS are diabetes mellitus, thyroid dysfunction, rheumatoid arthritis, pregnancy, obesity and osteoarthritis [12,13].

Comprehensive physical therapy is useful in the conservative treatment of people with CTS [14]. Despite the existence of significant opportunities for conservative treatment with a variety of physiotherapeutic agents, many people eventually undergo carpal tunnel release. In the literature on the subject, there is scarce research on work absences after carpal tunnel release or guidelines regarding the timing of safe return to work after surgery [3]. The results of the study by Katz et al. [15] indicate that a significant percentage of people (23\%) do not take up occupational activity 6 months after carpal tunnel release. According to the authors, this is the result of various economic and psychosocial factors [15].

The effectiveness of treatment methods used in this study was confirmed in the studies of other authors [16-19]. Whirlpool massage improves circulation and tissue tropism, as well as stimulates superficial sensory receptors and reduces the tension on soft tissues. The comprehensive effect of hydrotherapy and other physiotherapeutic treatments applied afterwards improves the effects of comprehensive physical therapy [16]. Sonotherapy applied to the carpal tunnel area is also useful. The ultrasound wave has anti-inflammatory effects, stimulates nerve regeneration and improves nerve conductivity [20]. Neuromobilization (nerve flossing) of the median nerve and nerve glide exercises in the carpal tunnel improve its mobility in this area [19]. Following patient education, nerve glide exercises can be performed at home as a supplement to comprehensive physical therapy [12].
The continuation of the research into the efficacy of conservative CTS treatment may be helpful in clinical practice when making therapeutic decisions, especially for patients who do not want to or cannot undergo carpal tunnel release for various reasons.

\begin{abstract}
Aim
This paper aims to assess the influence of selected factors on the long-term effects of conservative treatment in patients with CTS. The following factors were taken into account: age, sex, CTS grade (initial electrodiagnostic test result), previous treatment, onset and overuse of the hand during occupational work.
\end{abstract}

\section{MATERIAL AND METHODS}

The permission to conduct the study was granted by the Bioethics Committee of the University of Rzeszów (Resolution No. 4/11/2006). The study was conducted from September 2010 till the end of 2013 in St. Hedvig Provincial Hospital No. 2 in Rzeszów.

\section{Material}

The initial sample consisted of 74 individuals in whom unilateral or bilateral CTS was confirmed in an electrodiagnostic test. On the basis of the adopted exclusion criteria (trauma and significant hand dysfunction, history of cancer, no consent to participate in the study), 6 individuals were excluded from the study. Following neurological consultation, 68 individuals were referred for physical therapy in accordance with the research protocol. After 1 year, 19 individuals did not complete the research program and were excluded from further analysis:

- 11 individuals did not proceed to re-examination,

- 6 individuals participated in other forms of conservative treatment in this period,

- 2 individuals underwent carpal tunnel release.

The study protocol was completed by 49 individuals, with a mean age of 54.7 years, and the duration of symptoms 
2-5 years (average 2.8 years). Finally, 78 hands were assessed (45 right and 33 left ones). Based on the results of the initial electrodiagnostic test, the CTS was determined as mild (12 hands), moderate (45 hands) or severe (21 hands) (Table 1).

The comorbidities considered were thyroid dysfunction (hypo- and hyperthyroidism), spondyloarthritis, rheumatoid arthritis and post-stroke conditions.

The following figures show the occupational structure of the respondents and the occurrence of comorbidities predisposing to CTS (Figures 1 and 2).

Clinical symptoms such as pain (10-point Visual Analogue Scale - VAS), numbness, tingling, morning stiffness, vegetative disorders (dry skin, nail plate cracking) and difficulties in activities of daily living (10-point Activities of Daily Living Scale - ADL) were taken into account in the study. The range of motion (ROM) in the hand joints (Figure 3 ) and the pressure generated during the maximum cylindrical hand grip (Figure 4) were measured using an electronic hand function test set. The accuracy of the sensors used for computer measurements was $\pm 0.1 \%$ for the pressure sensor and $\pm 0.2 \%$ for the elongation sensor (ROM measurement) [21].

Phalen's and reverse Phalen's provocative tests were carried out. The evaluation of the median nerve conduction study included an electrodiagnostic test and an examination of the quality of 2-point discrimination. The electrodiagnostic test was performed with a Medtronic Keypoint device. Sensory and motor conductivity in the median nerve fibres was assessed. The nerve conduction study was carried out in a minimum temperature of $25^{\circ} \mathrm{C}$, in which the patient had stayed for at least $20 \mathrm{~min}$ before the test. The temperature of the examined hand was at least $32^{\circ} \mathrm{C}$. Based on the obtained electroneurographic parameters, distal motor latency (DML), distal sensory latency (DSL), compound motor action potential (CMAP), sensory nerve action potential (SNAP), and sensory conduction velocity (SCV) were used to assess the stage of the syndrome. Mild, moderate and severe grades of CTS were determined. The 2-point discrimination test was carried out in accordance with the guidelines of the American Society of Hand Surgery. A distance $\leq 6 \mathrm{~mm}$ was adopted as a normal result of the discrimination test [22].

The therapeutic program applied in the subjects included 10 whirlpool massage sessions of the hand, sonotherapy and median nerve glide exercises, which the subjects repeated as homework. Together with the whirlpool massage, sonotherapy constituted a preparation for the application of kinesitherapeutic techniques. Treat-

Table 1. Characteristics of the examined subjects with carpal tunnel syndrome (CTS) - the study conducted in September 2010 - December 2013 in St. Hedvig Provincial Hospital No. 2 in Rzeszów, Poland

\begin{tabular}{lc}
\hline \multicolumn{1}{c}{ Variable } & $\begin{array}{l}\text { Subjects } \\
(\mathrm{N}=49) \\
{[\mathrm{n}(\%)]}\end{array}$ \\
\hline Sex & $42(86)$ \\
women & $7(14)$ \\
men & \\
CTS cause & $37(76)$ \\
occupational work & $12(24)$ \\
other & \\
Incidence of CTS & $20(41)$ \\
unilateral & $29(59)$ \\
bilateral & \\
Comorbidities & $27(55)$ \\
yes & $22(45)$ \\
no & \\
History of physiotherapeutic treatment & $20(41)$ \\
yes & $29(59)$ \\
no & \\
Age & $16(33)$ \\
$<50$ years & $21(43)$ \\
$50-59$ years & $12(24)$ \\
$\geq 60$ years &
\end{tabular}




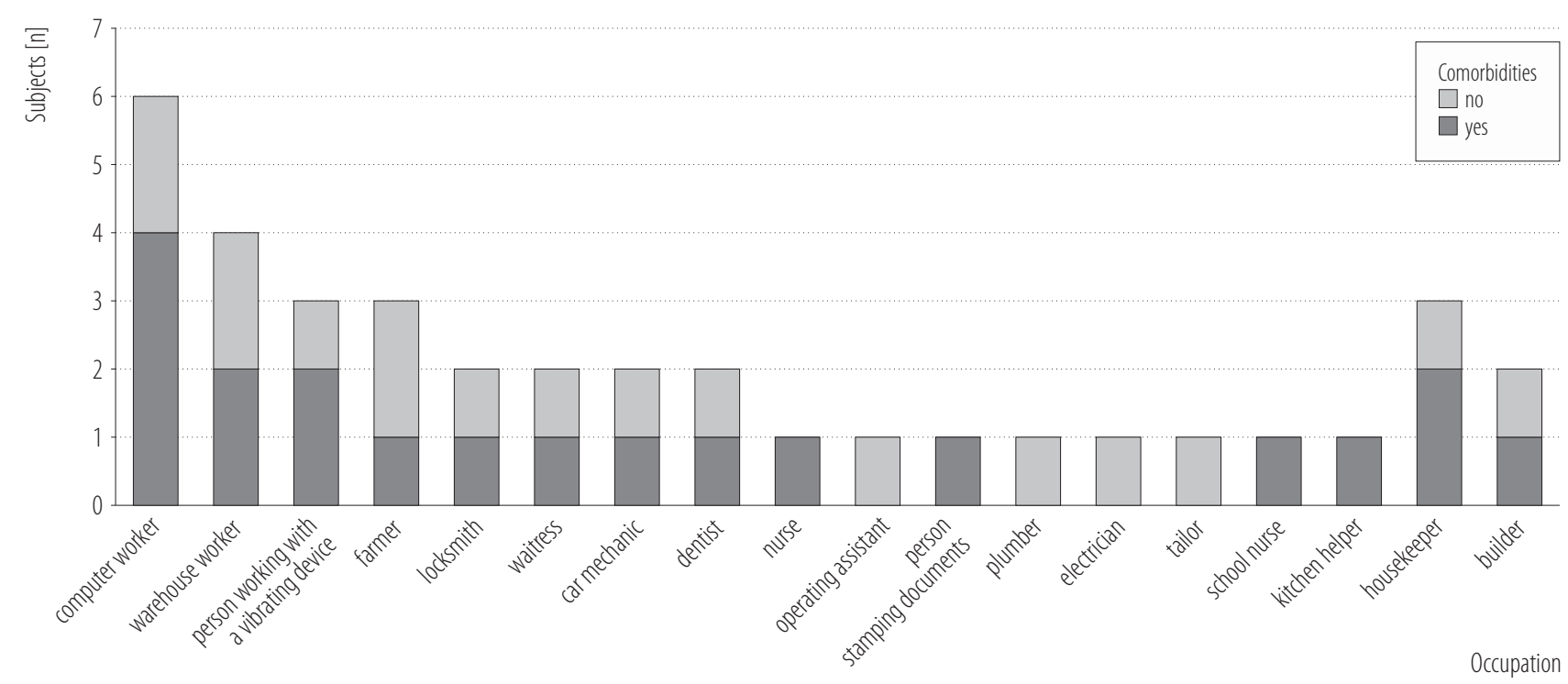

Figure 1. Occupational structure of the subjects who reported an occupational reason of carpal tunnel syndrome (CTS) in the study conducted in September 2010 - December 2013 in St. Hedvig Provincial Hospital No. 2 in Rzeszów, Poland

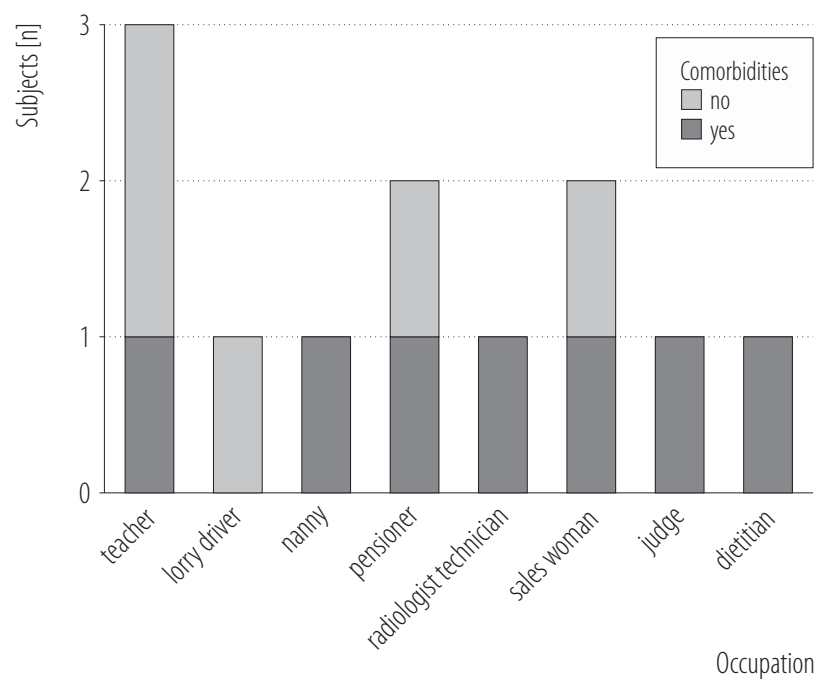

Figure 2. Occupational structure of the subjects who reported a non-occupational reason of carpal tunnel syndrome (CTS) in the study conducted in September 2010 - December 2013 in St. Hedvig Provincial Hospital No. 2 in Rzeszów, Poland

ments were performed with the Sonicator 740 device, using a head with an effective radiation area (ERA) of $5 \mathrm{~cm}^{2}$. An ultrasonic wave with a frequency of $1 \mathrm{MHz}$ was used. In all subjects, the applied ultrasound intensity was $0.6 \mathrm{~W} / \mathrm{cm}^{2}$ and the treatment energy was $1080 \mathrm{~J}$.

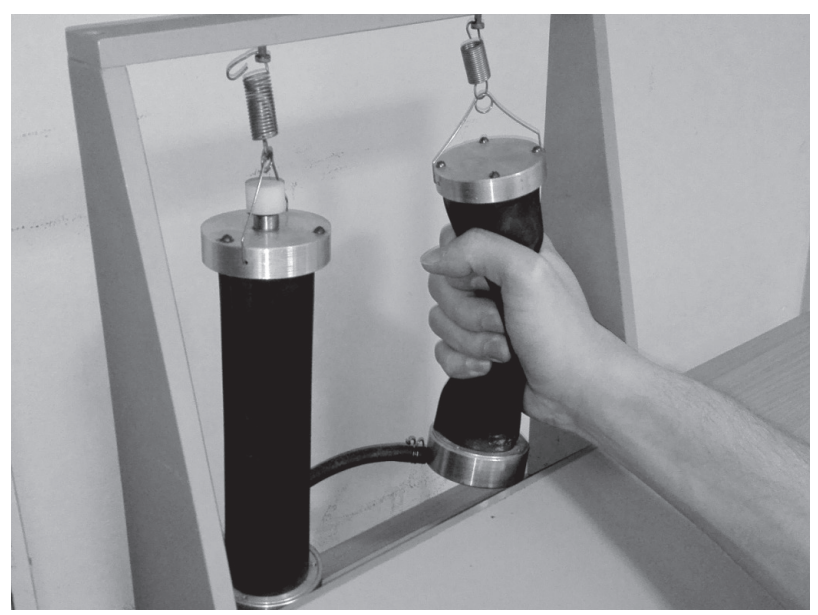

Photo: Monika Gąsior

Figure 3. Measurement of range of motion (ROM) in the hand joints

For the treatment area of about $10 \mathrm{~cm}^{2}$, the energy density was $108 \mathrm{~J} / \mathrm{cm}^{2}$ (Figure 5).

The analysis included examinations prior to the therapy (study 1) and 1 year after the end of the therapy (study 2). The description of the distribution of numerical measures of efficiency in studies 1 and 2, as well as for the treatment effect, contained information about the mean 


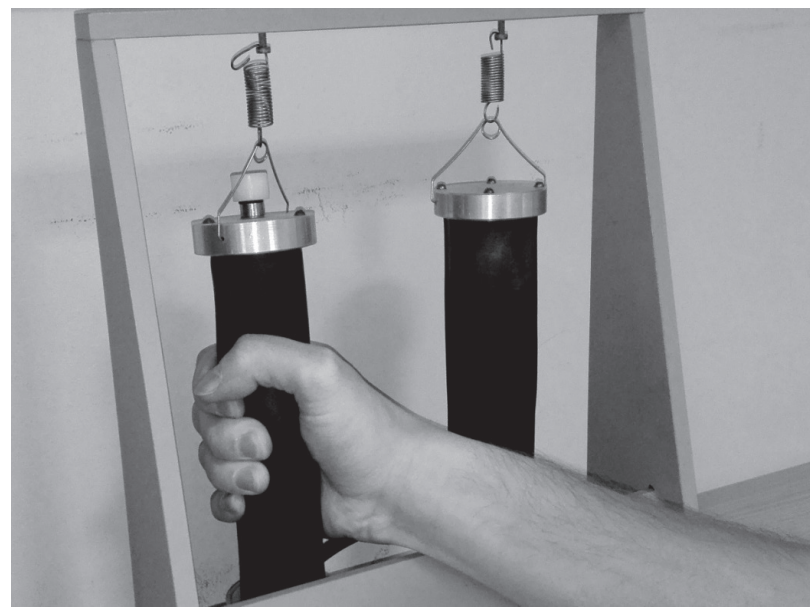

Photo: Monika Gąsior

Figure 4. Measurement of the pressure generated during the maximum cylindrical hand grip

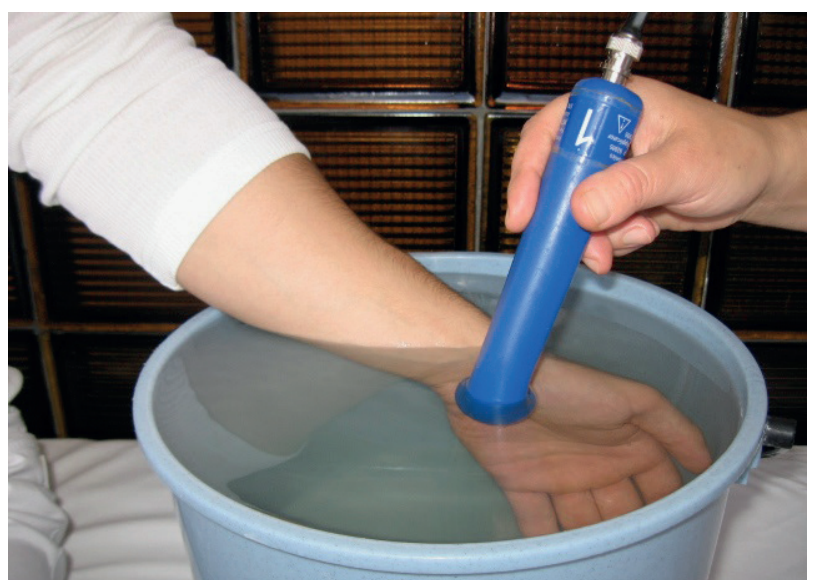

Photo: Monika Gąsior

Figure 5. Sonotherapy performed in the aquatic environment

and $95 \%$ confidence interval. For nominal features, the number and frequency of individual health events were reported (along with the 95\% confidence interval).

The statistical significance of the physical therapy effects was assessed using the Wilcoxon test (for numerical data) or McNemar's test (for dichotomous data), and the differences between the compared groups regarding the symptoms and functional status of the hands were assessed using the Mann-Whitney $U$ test, the Kruskal-Wallis test and $\chi^{2}$ independence test. The influence of quantitative factors on the effects of rehabilitation was also examined using the Spearman's rank correlation coefficient.

The tables present the test probability values ( $p$-value) for the statistical tests carried out. The results for which $\mathrm{p}<0.05$ (with results below 0.01 or 0.001 additionally highlighted) were considered significant.

\section{RESULTS}

One year after the end of the therapy (study 2), the subjects experienced a significant improvement in all the assessed parameters, along with symptoms reduction (except for the results of the reverse Phalen's test and the incidence of vegetative disorders) (Table 2).

In order to analyze the influence of age on the effects of treatment, the subjects were divided into 3 age groups:

$-<50$ years,

- 50-59 years,

- $\geq 60$ years.

One year after the end of the therapy (study 2), the lowest daytime pain after the therapy was reported in the age group $\geq 60$. The lowest level of nighttime pain was also reported in the age group $\geq 60$. The greatest difficulties in ADL were reported in people aged 50-59 (Table 3). In study 2, the largest ROM in the hand joints was recorded in people $\geq 60$ (Table 3 ). One year after the end of the treatment in the group of subjects $\geq 60$, a significant deterioration of Phalen's test results was recorded (Table 3). The best treatment effects, expressed by DML reduction and CMAP increase, were reported in people aged $<50$ (Table 3). The relationship between age and treatment effects was also assessed by means of the Spearman's rank correlation coefficient using ungrouped age values. In addition to the observed age-dependence of changes in amplitude in motor fibers, it was found that the improvement in DML (Figure 6) and DSL (Figure 7) decreases with age. The best effects of treatment, expressed by the remission of nighttime tingling, were also noted in the group of subjects $\geq 60$ (Table 4 ). 


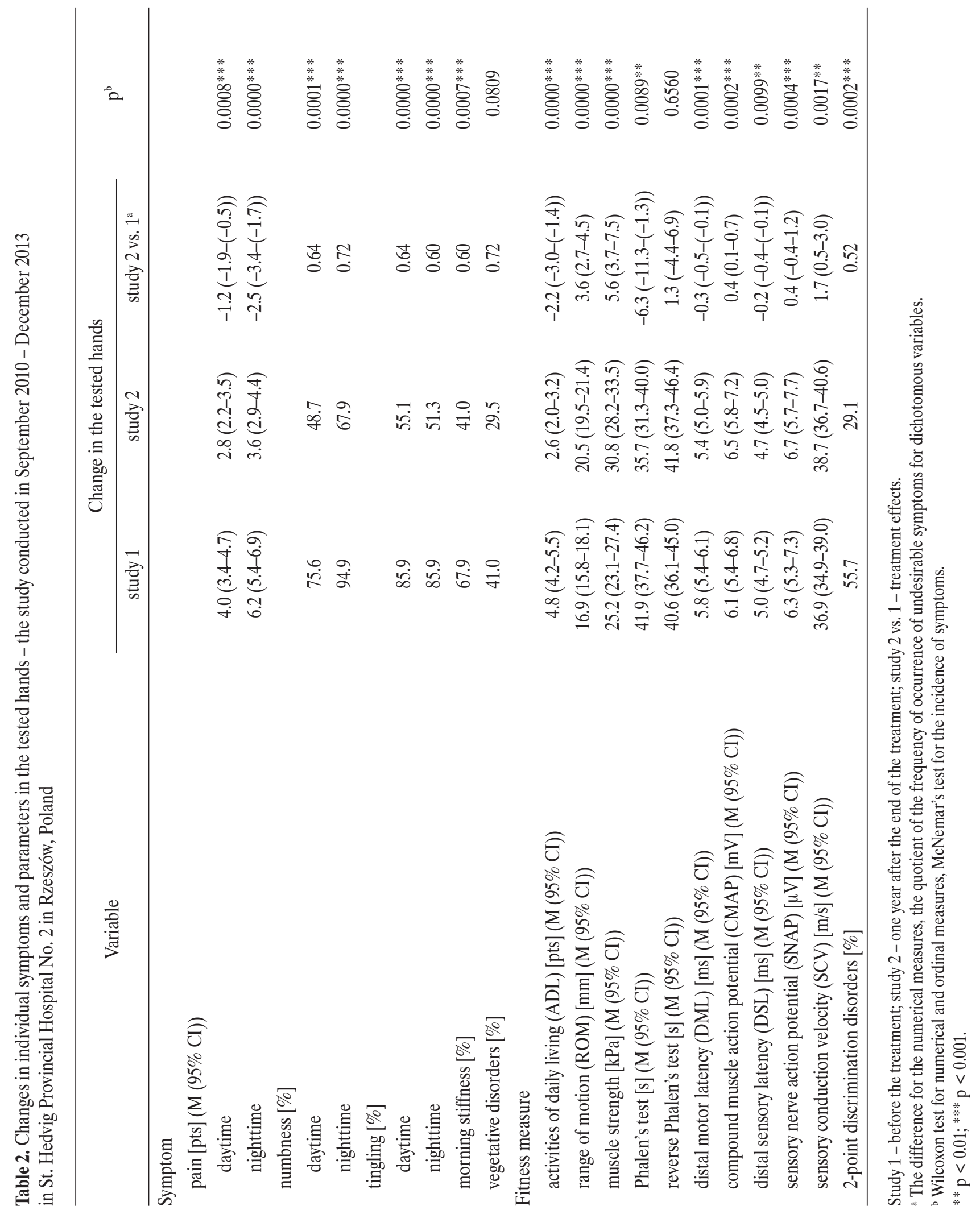


Table 3. Age-dependent changes in individual symptoms and parameters - the study conducted in September 2010 - December 2013 in St. Hedvig Provincial Hospital No. 2 in Rzeszów, Poland

\begin{tabular}{|c|c|c|c|c|}
\hline \multirow{2}{*}{ Variable } & \multicolumn{3}{|c|}{$\begin{array}{l}\text { Change dependent on subjects' age } \\
\qquad(\mathrm{M}(95 \% \mathrm{CI}))\end{array}$} & \multirow{2}{*}{$\mathrm{p}^{\mathrm{a}}$} \\
\hline & $\begin{array}{l}<50 \text { years } \\
(\mathrm{N}=25)\end{array}$ & $\begin{array}{l}50-59 \text { years } \\
(\mathrm{N}=33)\end{array}$ & $\begin{array}{l}\geq 60 \text { years } \\
(\mathrm{N}=20)\end{array}$ & \\
\hline \multicolumn{5}{|l|}{ Pain [pts] } \\
\hline \multicolumn{5}{|l|}{ daytime } \\
\hline study 1 & $3.96(2.63-5.29)$ & $4.36(3.27-5.46)$ & $3.60(2.46-4.74)$ & 0.5751 \\
\hline study 2 & $2.56(1.53-3.59)$ & $3.79(2.80-4.77)$ & $1.65(0.57-2.73)$ & $0.0157^{*}$ \\
\hline study 2 vs. study 1 & $-1.40(-2.77-(-0.03))$ & $-0.58(-1.69-0.54)$ & $-1.95(-3.23-(-0.67))$ & 0.3854 \\
\hline \multicolumn{5}{|l|}{ nighttime } \\
\hline study 1 & $6.36(5.27-7.45)$ & $6.61(5.35-7.87)$ & $5.15(3.76-6.54)$ & 0.1400 \\
\hline study 2 & $3.52(2.33-4.71)$ & $4.52(3.25-5.78)$ & $2.25(0.70-3.80)$ & $0.0397^{*}$ \\
\hline study 2 vs. study 1 & $-2.84(-4.55-(-1.13))$ & $-2.09(-3.21-(-0.98))$ & $-2.90(-4.65-(-1.15))$ & 0.5715 \\
\hline \multicolumn{5}{|l|}{ Activities of daily living (ADL) [pts] } \\
\hline study 1 & $4.20(3.22-5.18)$ & $5.36(4.37-6.36)$ & $4.65(2.99-6.31)$ & 0.2685 \\
\hline study 2 & $1.56(0.65-2.47)$ & $3.64(2.68-4.59)$ & $2.20(0.91-3.49)$ & $0.0073^{* *}$ \\
\hline study 2 vs. study 1 & $-2.64(-3.76-(-1.52))$ & $-1.73(-3.18-(-0.28))$ & $-2.45(-4.17-(-0.73))$ & 0.8067 \\
\hline \multicolumn{5}{|l|}{ Range of motion $(\mathrm{ROM})[\mathrm{mm}]$} \\
\hline study 1 & $16.2(13.3-19.1)$ & $16.3(14.8-17.8)$ & $18.8(17.1-20.5)$ & 0.0944 \\
\hline study 2 & $21.1(18.9-23.3)$ & $18.9(17.7-20.0)$ & $22.4(20.8-24.1)$ & $0.0011^{* *}$ \\
\hline study 2 vs. study 1 & $5.0(2.9-7.0)$ & $2.6(1.5-3.6)$ & $3.6(1.8-5.5)$ & 0.1887 \\
\hline \multicolumn{5}{|l|}{ Phalen's test $[\mathrm{s}]$} \\
\hline study 1 & $37.2(28.8-45.6)$ & $38.4(32.1-44.8)$ & $54.0(48.2-59.7)$ & $0.0009^{* * *}$ \\
\hline study 2 & $36.9(29.0-44.8)$ & $34.7(27.5-41.8)$ & $36.2(28.1-44.3)$ & 0.9007 \\
\hline study 2 vs. study 1 & $-0.3(-9.6-9.0)$ & $-3.8(-10.9-3.4)$ & $-17.8(-27.4-(-8.1))$ & $0.0363^{*}$ \\
\hline \multicolumn{5}{|l|}{$\begin{array}{l}\text { Electrodiagnostic parameter } \\
\text { (treatment effect) }\end{array}$} \\
\hline distal motor latency (DML) [ms] & $-0.50(-0.76-(-0.24))$ & $-0.33(-0.77-0.12)$ & $-0.09(-0.41-0.23)$ & 0.0512 \\
\hline $\begin{array}{l}\text { compound muscle action potential } \\
\text { (CMAP) }[\mathrm{mV}]\end{array}$ & $0.83(0.18-1.48)$ & $-0.06(-0.51-0.40)$ & $0.66(0.09-1.23)$ & $0.0110^{*}$ \\
\hline distal sensory latency (DSL) [ms] & $-0.48(-0.83-(-0.12))$ & $-0.22(-0.54-0.10)$ & $-0.04(-0.26-0.18)$ & 0.1204 \\
\hline $\begin{array}{l}\text { sensory nerve action potential } \\
\text { (SNAP) }[\mu \mathrm{V}]\end{array}$ & $0.04(-0.84-0.91)$ & $0.44(-1.26-2.13)$ & $0.70(-0.17-1.57)$ & 0.8947 \\
\hline $\begin{array}{l}\text { sensory conduction velocity } \\
(\mathrm{SCV})[\mathrm{m} / \mathrm{s}]\end{array}$ & $0.76(-1.70-3.22)$ & $2.02(-0.18-4.22)$ & $2.35(0.52-4.19)$ & 0.5913 \\
\hline
\end{tabular}

Study 1 - before the treatment; study 2 - one year after the end of the treatment; study 2 vs. 1 - treatment effects.

${ }^{a}$ Kruskal-Wallis test.

* $\mathrm{p}<0.05 ;{ }^{* *} \mathrm{p}<0.01 ; * * \mathrm{p}<0.001$. 


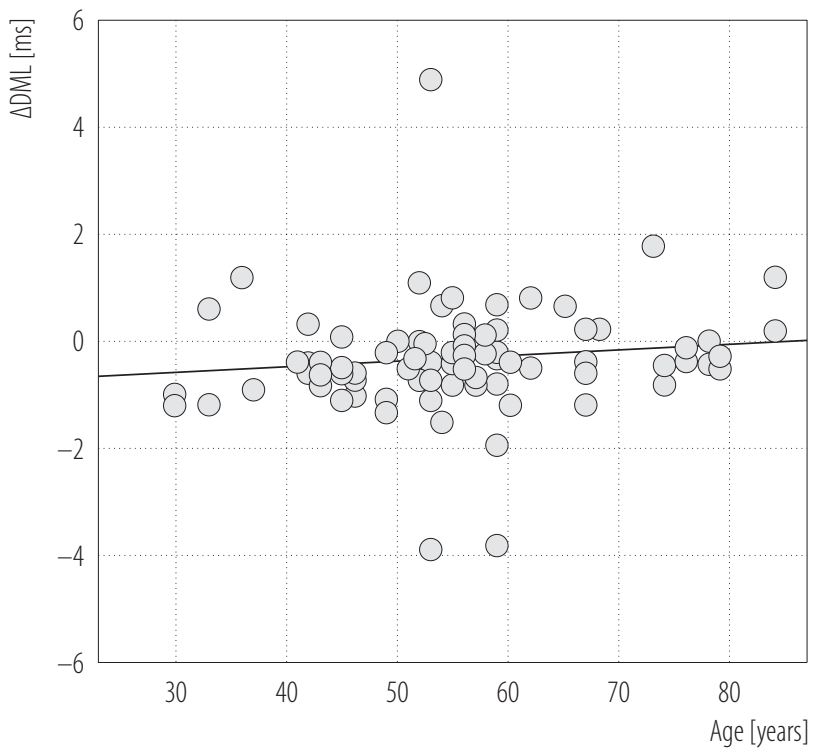

$\mathrm{R}$ - Spearman's rank correlation coefficient. $* \mathrm{p}<0.05$.

Figure 6. Changes in distal motor latency (DML) of the median nerve depending on the age of the subjects in the study conducted in September 2010 - December 2013 in St. Hedvig Provincial Hospital No. 2 in Rzeszów, Poland

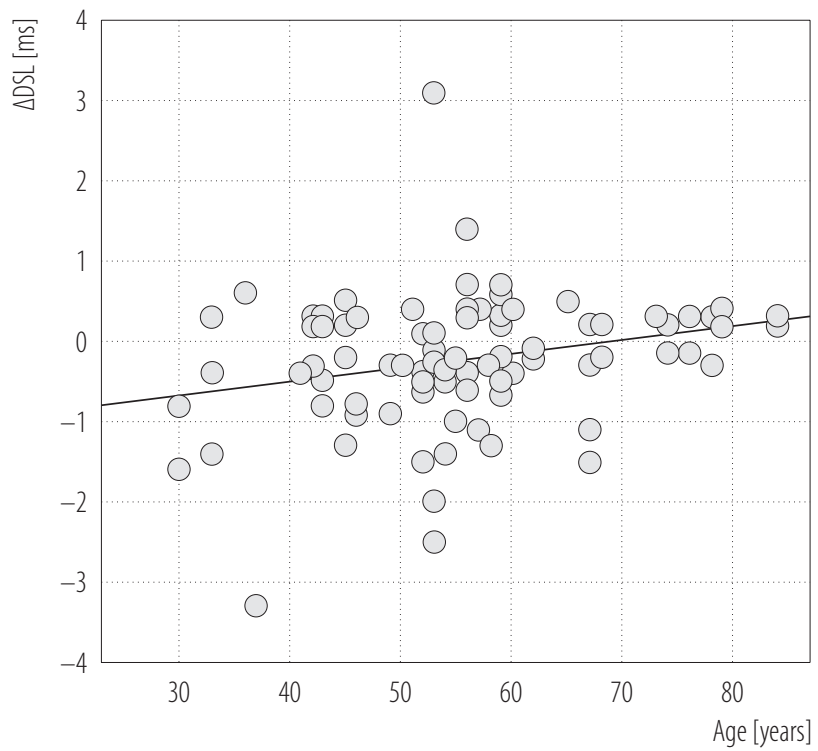

$\mathrm{R}$ - Spearman's rank correlation coefficient. $* \mathrm{p}<0.05$.

Figure 7. Changes in distal sensory latency (DSL) of the median nerve depending on the age of the subjects in the study conducted in September 2010 - December 2013 in St. Hedvig Provincial Hospital No. 2 in Rzeszów, Poland

Table 4. Change of symptoms depending on the subjects' age - the study conducted in September 2010 - December 2013 in St. Hedvig Provincial Hospital No. 2 in Rzeszów, Poland

\begin{tabular}{|c|c|c|c|c|c|c|c|}
\hline \multirow{3}{*}{$\begin{array}{l}\text { Influence of treatment } \\
\text { effects on the symptom }\end{array}$} & \multicolumn{6}{|c|}{ Cured cases in age groups } & \multirow{3}{*}{$\mathrm{p}^{\mathrm{b}}$} \\
\hline & \multicolumn{2}{|c|}{$\begin{array}{l}<50 \text { years } \\
(\mathrm{N}=25)\end{array}$} & \multicolumn{2}{|c|}{$\begin{array}{c}50-59 \text { years } \\
(\mathrm{N}=33)\end{array}$} & \multicolumn{2}{|c|}{$\begin{array}{l}\geq 60 \text { years } \\
(\mathrm{N}=20)\end{array}$} & \\
\hline & $\mathrm{n} / \mathrm{N}^{\mathrm{a}}$ & $\%(95 \% \mathrm{CI})$ & $\mathrm{n} / \mathrm{N}^{\mathrm{a}}$ & $\%(95 \% \mathrm{CI})$ & $\mathrm{n} / \mathrm{N}^{\mathrm{a}}$ & $\%(95 \% \mathrm{CI})$ & \\
\hline \multicolumn{8}{|l|}{ Numbness } \\
\hline daytime & $8 / 17$ & $47.1(23.0-72.2)$ & $10 / 25$ & $40.0(21.1-61.3)$ & $5 / 17$ & $29.4(10.3-56.0)$ & 0.5679 \\
\hline nighttime & $7 / 25$ & $28.0(12.1-49.4)$ & $6 / 30$ & $20.0(7.7-38.6)$ & $9 / 19$ & $47.4(24.4-71.1)$ & 0.1210 \\
\hline \multicolumn{8}{|l|}{ Tingling } \\
\hline daytime & $10 / 21$ & $47.6(25.7-70.2)$ & $7 / 27$ & $25.9(11.1-46.3)$ & $10 / 19$ & $52.6(28.9-75.6)$ & 0.1362 \\
\hline nighttime & $6 / 24$ & $25.0(9.8-46.7)$ & $11 / 25$ & $44.0(24.4-65.1)$ & $14 / 18$ & $77.8(52.4-93.6)$ & $0.0030^{* *}$ \\
\hline Morning stiffness & $13 / 18$ & $72.2(46.5-90.3)$ & $11 / 27$ & $40.7(22.4-61.2)$ & $4 / 8$ & $50.0(15.7-84.3)$ & 0.1150 \\
\hline Vegetative disorders & $4 / 8$ & $50.0(15.7-84.3)$ & $8 / 19$ & $42.1(20.3-66.5)$ & $3 / 5$ & $60.0(14.7-94.7)$ & 0.7593 \\
\hline
\end{tabular}

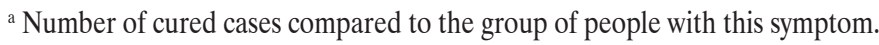

${ }^{\mathrm{b}}$ Chi-square test of independence.

** $\mathrm{p}<0.01$. 
Table 5. Revese Phalen's test results depending on the subject's sex - the study conducted in September 2010 - December 2013 in St. Hedvig Provincial Hospital No. 2 in Rzeszów, Poland

\begin{tabular}{|c|c|c|c|}
\hline \multirow[t]{2}{*}{ Study } & \multicolumn{2}{|c|}{$\begin{array}{c}\text { Reverse Phalen's test } \\
{[\mathrm{s}]} \\
(\mathrm{M}(95 \% \mathrm{CI})) \\
\end{array}$} & \multirow[t]{2}{*}{$\mathrm{p}^{\mathrm{a}}$} \\
\hline & $\begin{array}{c}\text { woman } \\
(\mathrm{N}=69)\end{array}$ & $\begin{array}{c}\operatorname{man} \\
(\mathrm{N}=10)\end{array}$ & \\
\hline Study 1 & $38.8(34.1-43.6)$ & $54.0(45.8-62.2)$ & $0.0281^{*}$ \\
\hline Study 2 & $42.6(37.8-47.3)$ & $37.4(21.9-52.9)$ & 0.4446 \\
\hline Study 2 vs. study 1 & $3.7(-2.0-9.5)$ & $-16.6(-35.1-1.9)$ & $0.0156^{*}$ \\
\hline
\end{tabular}

Study 1 - before the treatment; study 2 - one year after the end of the treatment; study 2 vs. 1 - treatment effects.

${ }^{a}$ Mann-Whitney test.

** $\mathrm{p}<0.01$.

Table 6. Individual symptoms disappearance after the therapy depending on the initial result of electrodiagnostic test the study conducted in September 2010 - December 2013 in St. Hedvig Provincial Hospital No. 2 in Rzeszów, Poland

\begin{tabular}{|c|c|c|c|c|c|c|c|}
\hline \multirow{3}{*}{$\begin{array}{l}\text { Influence of treatment } \\
\text { effects on the symptom }\end{array}$} & \multicolumn{6}{|c|}{ Cured cases } & \multirow{3}{*}{$\mathrm{p}^{\mathrm{b}}$} \\
\hline & \multicolumn{2}{|c|}{ CTS: mild } & \multicolumn{2}{|c|}{ CTS: moderate } & \multicolumn{2}{|c|}{ CTS: severe } & \\
\hline & $\mathrm{n} / \mathrm{N}^{\mathrm{a}}$ & $\%(95 \% \mathrm{CI})$ & $\mathrm{n} / \mathrm{N}^{\mathrm{a}}$ & $\%(95 \% \mathrm{CI})$ & $\mathrm{n} / \mathrm{N}^{\mathrm{a}}$ & $\%(95 \% \mathrm{CI})$ & \\
\hline \multicolumn{8}{|l|}{ Numbness } \\
\hline daytime & $7 / 8$ & $87.5(47.3-99.7)$ & $12 / 32$ & $37.5(21.1-56.3)$ & $4 / 19$ & $21.1(6.0-45.6)$ & $0.0052^{* *}$ \\
\hline nighttime & $3 / 9$ & $33.3(7.5-70.1)$ & $12 / 44$ & $27.3(15.0-42.8)$ & $7 / 21$ & $33.3(14.6-57.0)$ & 0.8549 \\
\hline \multicolumn{8}{|l|}{ Tingling } \\
\hline daytime & $8 / 11$ & $72.7(39.0-94.0)$ & $14 / 37$ & $37.8(22.5-55.2)$ & $5 / 19$ & $26.3(9.1-51.2)$ & $0.0399 *$ \\
\hline nighttime & $4 / 9$ & $44.4(13.7-78.8)$ & $15 / 38$ & $39.5(24.0-56.6)$ & $12 / 20$ & $60.0(36.0-80.9)$ & 0.3272 \\
\hline Morning stiffness & $6 / 9$ & $66.7(29.9-92.5)$ & $13 / 26$ & $50.0(29.9-70.1)$ & $9 / 18$ & $50.0(26.0-74.0)$ & 0.6594 \\
\hline Vegetative disorders & $3 / 5$ & $60.0(14.7-94.7)$ & $10 / 20$ & $50.0(27.2-72.8)$ & $2 / 7$ & $28.6(3.7-71.0)$ & 0.5051 \\
\hline
\end{tabular}

${ }^{\text {a }}$ Number of cured cases compared to the group of people with this symptom.

${ }^{\mathrm{b}}$ Chi-square test of independence.

$* \mathrm{p}<0.05 ; * \mathrm{p}<0.01$.

One year after the end of the treatment, the results of reverse Phalen's test deteriorated in men (Table 5).

Better treatment effects expressed by the remission of daytime numbness were noted in individuals with better initial electrodiagnostic test results (Table 6).

One year after the end of the therapy, Phalen's test results deteriorated in subjects with moderate CTS (Table 7).

Greater improvement in ROM was observed in subjects undergoing renewed conservative treatment (Table 8).
In the analysis of changes in sensory quality, it was assumed that negative values represented a deterioration of sensation by a sufficient number of levels, while positive values represent sensory improvement. It was shown that the distribution of sensory changes after the treatment was only determined by undertaking prior treatment (the difference between groups close to the level of statistical significance $\mathrm{p}=0.0621$ ). After the treatment, a greater improvement was achieved in the group subjected to renewed treatment. 
Table 7. Phalen's test results depending on the initial result of the electrodiagnostic test (ET) - the study conducted in September 2010 - December 2013 in St. Hedvig Provincial Hospital No. 2 in Rzeszów, Poland

\begin{tabular}{|c|c|c|c|c|}
\hline \multirow[t]{2}{*}{ Study } & \multicolumn{3}{|c|}{$\begin{array}{c}\text { Phalen's test } \\
{[\mathrm{s}]} \\
(\mathrm{M}(95 \% \mathrm{CI}))\end{array}$} & \multirow[t]{2}{*}{$\mathrm{p}^{\mathrm{a}}$} \\
\hline & $\begin{array}{l}\text { CTS: mild } \\
(\mathrm{N}=12)\end{array}$ & $\begin{array}{l}\text { CTS: moderate } \\
\quad(\mathrm{N}=45)\end{array}$ & $\begin{array}{c}\text { CTS: severe } \\
(\mathrm{N}=21)\end{array}$ & \\
\hline Study 1 & $40.7(28.2-53.2)$ & $45.7(40.4-51.1)$ & $35.2(26.6-43.8)$ & 0.2306 \\
\hline Study 2 & $44.5(33.9-55.1)$ & $33.7(28.4-39.0)$ & $35.4(25.4-45.5)$ & 0.2100 \\
\hline Study 2 vs. study 1 & $3.8(-13.3-20.9)$ & $-12.1(-17.9-(-6.2))$ & $0.2(-9.5-10.0)$ & $0.0314 *$ \\
\hline
\end{tabular}

Study 1 - before the treatment; study 2 - one year after the end of the treatment; study 2 vs. 1 - treatment effects.

$\mathrm{N}$ - number of hands.

${ }^{a}$ Kruskal-Wallis test.

$* \mathrm{p}<0.05$.

Table 8. Range of motion (ROM) in the examined hands depending on the previously undertaken treatment - the study conducted in September 2010 - December 2013 in St. Hedvig Provincial Hospital No. 2 in Rzeszów, Poland

\begin{tabular}{|c|c|c|c|}
\hline \multirow{2}{*}{ Study } & \multicolumn{2}{|c|}{$\begin{array}{c}\text { ROM } \\
{[\mathrm{mm}]} \\
(\mathrm{M}(95 \% \mathrm{CI}))\end{array}$} & \multirow{2}{*}{$\mathrm{p}^{\mathrm{a}}$} \\
\hline & $\begin{array}{l}\text { physiotherapeutic treatment } \\
\qquad(\mathrm{N}=28)\end{array}$ & $\begin{array}{l}\text { no physiotherapeutic treatment } \\
\qquad(\mathrm{N}=48)\end{array}$ & \\
\hline Study 1 & $15.8(13.7-17.8)$ & $17.6(16.2-19.0)$ & 0.1777 \\
\hline Study 2 & $20.8(19.1-22.6)$ & $20.3(19.1-21.5)$ & 0.8015 \\
\hline Study 2 vs. study 1 & $5.1(3.2-6.9)$ & $2.7(1.8-3.6)$ & $0.0397^{*}$ \\
\hline
\end{tabular}

Study 1 - before the treatment; study 2 - one year after the end of the treatment; study 2 vs. 1 - treatment effects.

$\mathrm{N}$ - number of hands.

${ }^{a}$ Mann-Whitney test.

$* \mathrm{p}<0.05$.

In this group, the improvement concerned $57 \%$ of people, and in the group treated for the first time less than a half, that is about $32 \%$ (Figure 8).

Better effects of treatment expressed as a reduction in nighttime pain were observed in people without comorbidities (Table 9).

Better treatment effects expressed by remission of vegetative disorders were noted in patients without comorbidities (Table 10).

People with comorbidities had slightly higher ROM before and after the end of the therapy. In turn, the effect of the therapy was better in the group of patients with comorbidities, but not so much that it could be considered statistically significant (Table 11).

A lower level of daytime pain and nighttime pain after the end of the therapy was reported in the subjects not overusing their hand during occupational work (Table 12).

It was found that hand overuse during occupational work badly affected its condition after treatment. The effect of treatment was worse in people in whom the cause of CTS was not associated with occupational work. This applied 
Table 9. Nighttime pain in the examined hands depending on the presence of comorbidities - the study conducted in September 2010 - December 2013 in St. Hedvig Provincial Hospital No. 2 in Rzeszów, Poland

\begin{tabular}{|c|c|c|c|}
\hline \multirow{2}{*}{ Study } & \multicolumn{2}{|c|}{$\begin{array}{c}\text { Nighttime pain } \\
\text { [pts] } \\
(\mathrm{M}(95 \% \mathrm{CI}))\end{array}$} & \multirow{2}{*}{$\mathrm{p}^{\mathrm{a}}$} \\
\hline & $\begin{array}{l}\text { comorbidities } \\
(\mathrm{N}=48)\end{array}$ & $\begin{array}{l}\text { no comorbidities } \\
\quad(\mathrm{N}=30)\end{array}$ & \\
\hline Study 1 & $5.56(4.60-6.53)$ & $7.10(6.10-8.10)$ & $0.0431^{*}$ \\
\hline Study 2 & $3.25(2.19-4.31)$ & $4.20(3.14-5.26)$ & 0.1384 \\
\hline Study 2 vs. study 1 & $-2.31(-3.35-(-1.28))$ & $-2.90(-4.29-(-1.51))$ & 0.2944 \\
\hline
\end{tabular}

Study 1 - before the treatment; study 2 - one year after the end of the treatment; study 2 vs. 1 - treatment effects.

$\mathrm{N}$ - number of hands.

${ }^{a}$ Mann-Whitney test.

$* p<0.05$.

Table 10. Individual symptoms which subsided after the treatment depending on the presence of comorbidities - the study conducted in September 2010 - December 2013 in St. Hedvig Provincial Hospital No. 2 in Rzeszów, Poland

\begin{tabular}{lccccc}
\hline \multirow{2}{*}{$\begin{array}{l}\text { Influence of treatment effects } \\
\text { on the symptom }\end{array}$} & \multicolumn{3}{c}{ Cured cases } & \multirow{2}{c}{$\mathrm{p}^{\mathrm{b}}$} \\
\cline { 2 - 4 } & $\mathrm{n} / \mathrm{N}^{\mathrm{a}}$ & $\%(95 \% \mathrm{CI})$ & $\mathrm{n} / \mathrm{N}^{\mathrm{a}}$ & $\%(95 \% \mathrm{CI})$ & \\
\cline { 2 - 4 } $\begin{array}{l}\text { Numbness } \\
\quad \text { daytime }\end{array}$ & $15 / 40$ & $37.5(22.7-54.2)$ & $8 / 19$ & $42.1(20.3-66.5)$ & 0.7347 \\
$\quad$ nighttime & $16 / 44$ & $36.4(22.4-52.2)$ & $6 / 30$ & $20.0(7.7-38.6)$ & 0.1305 \\
Tingling & & & & & \\
$\quad$ daytime & $19 / 45$ & $42.2(27.7-57.8)$ & $8 / 22$ & $36.4(17.2-59.3)$ & 0.6461 \\
$\quad$ nighttime & $21 / 40$ & $52.5(36.1-68.5)$ & $10 / 27$ & $37.0(19.4-57.6)$ & 0.2131 \\
Morning stiffness & $17 / 32$ & $53.1(34.7-70.9)$ & $11 / 21$ & $52.4(29.8-74.3)$ & 0.9577 \\
Vegetative disorders & $7 / 20$ & $35.0(15.4-59.2)$ & $8 / 12$ & $66.7(34.9-90.1)$ & 0.0822 \\
\hline
\end{tabular}

${ }^{a}$ Number of cured cases (n) compared to the group of people with this symptom (N).

${ }^{\mathrm{b}}$ Chi-square test of independence.

to the majority of symptoms tested, and in particular to daytime tingling ( $p=0.0032$ ) (Table 13).

Better results of the treatment in terms of improving the efficiency of ADL were noted in people not overusing the hand during their occupational work. In this group, the mean improvement in ADL level was 4.2 pts while in the second group only 1.6 pts (Table 14).
In people not overusing their hands during their occupational work, a better treatment effect was obtained, expressed by the improvement of ROM; however, the difference between the groups was not statistically significant $(\mathrm{p}=0.3468)$ (Table 15).

There was no correlation between the changes in the measurement of the pressure generated during the cylindri- 
Table 11. Range of motion (ROM) in the examined hands depending on the presence of comorbidities - the study conducted in September 2010 - December 2013 in St. Hedvig Provincial Hospital No. 2 in Rzeszów, Poland

\begin{tabular}{|c|c|c|c|}
\hline \multirow{2}{*}{ Study } & \multicolumn{2}{|c|}{$\begin{array}{c}\text { ROM } \\
{[\mathrm{mm}]} \\
(\mathrm{M}(95 \% \mathrm{CI}))\end{array}$} & \multirow[t]{2}{*}{$\mathrm{p}^{\mathrm{a}}$} \\
\hline & $\begin{array}{l}\text { comorbidities } \\
(\mathrm{N}=48)\end{array}$ & $\begin{array}{c}\text { no comorbidities } \\
(\mathrm{N}=28)\end{array}$ & \\
\hline Study 1 & $18.2(17.0-19.4)$ & $14.7(12.5-16.9)$ & $0.0169^{*}$ \\
\hline Study 2 & $21.0(19.8-22.2)$ & $19.6(17.9-21.2)$ & 0.0694 \\
\hline Study 2 vs. study 1 & $2.8(1.9-3.8)$ & $4.9(3.1-6.6)$ & 0.1309 \\
\hline
\end{tabular}

Study 1 - before the treatment; study 2 - one year after the end of the treatment; study 2 vs. 1 - treatment effects.

${ }^{a}$ Mann-Whitney test.

$* p<0.05$.

Table 12. Pain in the hands tested depending on the nature of occupational work - the study conducted in September 2010 December 2013 in St. Hedvig Provincial Hospital No. 2 in Rzeszów, Poland

\begin{tabular}{|c|c|c|c|}
\hline \multirow[t]{2}{*}{ Variable } & \multicolumn{2}{|c|}{$\begin{array}{c}\text { Pain } \\
\text { [pts] } \\
(\mathrm{M}(95 \% \mathrm{CI}))\end{array}$} & \multirow[t]{2}{*}{$\mathrm{p}^{\mathrm{a}}$} \\
\hline & $\begin{array}{l}\text { occupational hand overuse } \\
\qquad(\mathrm{N}=60)\end{array}$ & $\begin{array}{l}\text { no occupational hand overuse } \\
\qquad(\mathrm{N}=18)\end{array}$ & \\
\hline \multicolumn{4}{|l|}{ Daytime pain } \\
\hline study 1 & $4.27(3.53-5.00)$ & $3.28(1.66-4.89)$ & 0.2218 \\
\hline study 2 & $3.23(2.52-3.95)$ & $1.56(0.59-2.52)$ & $0.0201 *$ \\
\hline study 2 vs. study 1 & $-1.03(-1.84-(-0.22))$ & $-1.72(-3.25-(-0.20))$ & 0.4131 \\
\hline \multicolumn{4}{|l|}{ Nighttime pain } \\
\hline study 1 & $6.50(5.72-7.28)$ & $5.00(3.31-6.69)$ & 0.0845 \\
\hline study 2 & $4.05(3.20-4.90)$ & $2.17(0.48-3.85)$ & $0.0195^{*}$ \\
\hline study 2 vs. study 1 & $-2.45(-3.41-(-1.49))$ & $-2.83(-4.48-(-1.19))$ & 0.6089 \\
\hline
\end{tabular}

Study 1 - before the treatment; study 2 - one year after the end of the treatment; study 2 vs. 1 - treatment effects.

${ }^{a}$ Mann-Whitney test.

$* p<0.05$.

Table 13. Incidence of symptoms in the examined hands depending on the nature of occupational work - the study conducted in September 2010 - December 2013 in St. Hedvig Provincial Hospital No. 2 in Rzeszów, Poland

\begin{tabular}{|c|c|c|c|c|c|}
\hline \multirow{3}{*}{$\begin{array}{l}\text { Symptoms which subsided } \\
\text { after the treatment }\end{array}$} & \multicolumn{4}{|c|}{ Symptoms incidence } & \multirow{3}{*}{$\mathrm{p}^{\mathrm{b}}$} \\
\hline & \multicolumn{2}{|c|}{ occupational hand overuse } & \multicolumn{2}{|c|}{ no occupational hand overuse } & \\
\hline & $\mathrm{n} / \mathrm{N}^{\mathrm{a}}$ & $\%(95 \% \mathrm{CI})$ & $\mathrm{n} / \mathrm{N}^{\mathrm{a}}$ & $\%(95 \% \mathrm{CI})$ & \\
\hline \multicolumn{6}{|l|}{ Numbness } \\
\hline daytime & $16 / 45$ & $35.6(21.9-51.2)$ & $7 / 14$ & $50.0(23.0-77.0)$ & 0.3332 \\
\hline nighttime & $16 / 58$ & $27.6(16.7-40.9)$ & $6 / 16$ & $37.5(15.2-64.6)$ & 0.4424 \\
\hline
\end{tabular}


Table 13. Incidence of symptoms in the examined hands depending on the nature of occupational work - the study conducted in September 2010 - December 2013 in St. Hedvig Provincial Hospital No. 2 in Rzeszów, Poland - cont.

\begin{tabular}{lccccc}
\hline \multirow{2}{*}{$\begin{array}{c}\text { Symptoms which subsided } \\
\text { after the treatment }\end{array}$} & \multicolumn{4}{c}{ Symptoms incidence } & \\
\cline { 2 - 4 } & \multicolumn{2}{c}{ occupational hand overuse } & no occupational hand overuse & $\mathrm{p}^{\mathrm{b}}$ \\
\cline { 2 - 4 } Tingling & $\mathrm{n} / \mathrm{N}^{\mathrm{a}}$ & $\%(95 \% \mathrm{CI})$ & $\mathrm{n} / \mathrm{N}^{\mathrm{a}}$ & $\%(95 \% \mathrm{CI})$ & \\
$\quad$ daytime & $15 / 50$ & $30.0(17.9-44.6)$ & $12 / 17$ & $70.6(44.0-89.7)$ & $0.0032^{* *}$ \\
$\quad$ nighttime & $22 / 52$ & $42.3(28.7-56.8)$ & $9 / 15$ & $60.0(32.3-83.7)$ & 0.2260 \\
Morning stiffness & $25 / 44$ & $56.8(41.0-71.7)$ & $3 / 9$ & $33.3(7.5-70.1)$ & 0.1985 \\
Vegetative disorders & $11 / 26$ & $42.3(23.3-63.1)$ & $4 / 6$ & $66.7(22.3-95.7)$ & 0.2811 \\
\hline
\end{tabular}

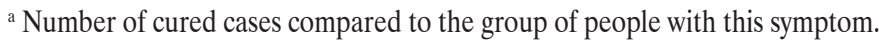

${ }^{\mathrm{b}}$ Chi-square test of independence.

$* * \mathrm{p}<0.01$.

Table 14. Difficulties in activities of daily living (ADL) depending on the nature of occupational work - the study conducted in September 2010 - December 2013 in St. Hedvig Provincial Hospital No. 2 in Rzeszów, Poland

\begin{tabular}{|c|c|c|c|}
\hline \multirow[t]{2}{*}{ Study } & \multicolumn{2}{|c|}{$\begin{array}{c}\text { ADL } \\
{[\mathrm{pts}]} \\
(\mathrm{M}(95 \% \mathrm{CI}))\end{array}$} & \multirow[t]{2}{*}{$\mathrm{p}^{\mathrm{a}}$} \\
\hline & $\begin{array}{l}\text { occupational hand overuse } \\
\qquad(\mathrm{N}=60)\end{array}$ & $\begin{array}{l}\text { no occupational hand overuse } \\
\qquad(\mathrm{N}=18)\end{array}$ & \\
\hline Study 1 & $4.43(3.70-5.17)$ & $6.06(4.65-7.46)$ & $0.0463 *$ \\
\hline Study 2 & $2.82(2.09-3.54)$ & $1.89(0.80-2.98)$ & 0.2309 \\
\hline Study 2 vs. study 1 & $-1.62(-2.54-(-0.69))$ & $-4.17(-5.54-(-2.79))$ & $0.0087^{* *}$ \\
\hline
\end{tabular}

Study 1 - before the treatment; study 2 - one year after the end of the treatment; study 2 vs. 1 - treatment effects.

${ }^{a}$ Mann-Whitney test.

$* \mathrm{p}<0.05 ; * \mathrm{p}<0.01$.

Table 15. Range of motion (ROM) in the hands tested, depending on the nature of the occupational work performed - the study conducted in September 2010 - December 2013 in St. Hedvig Provincial Hospital No. 2 in Rzeszów, Poland

\begin{tabular}{|c|c|c|c|}
\hline \multirow[t]{2}{*}{ Study } & \multicolumn{2}{|c|}{$\begin{array}{c}\text { ROM } \\
{[\mathrm{mm}]} \\
(\mathrm{M}(95 \% \mathrm{CI}))\end{array}$} & \multirow[t]{2}{*}{$\mathrm{p}^{\mathrm{a}}$} \\
\hline & $\begin{array}{l}\text { occupational hand overuse } \\
\qquad(\mathrm{N}=58)\end{array}$ & $\begin{array}{l}\text { no occupational hand overuse } \\
\qquad(\mathrm{N}=18)\end{array}$ & \\
\hline Study 1 & $17.1(15.8-18.4)$ & $16.3(13.5-19.1)$ & 0.6849 \\
\hline Study 2 & $20.6(19.5-21.6)$ & $20.3(18.0-22.6)$ & 0.7759 \\
\hline Study 2 vs. study 1 & $3.5(2.4-4.5)$ & $4.0(2.0-5.9)$ & 0.3468 \\
\hline
\end{tabular}

Study 1 - before the treatment; study 2 - one year after the end of the treatment; study 2 vs. 1 - treatment effects.

${ }^{a}$ Mann-Whitney test. 
cal grip and the nature of occupational work performed $(\mathrm{p}=0.4557)$.

There was no correlation between changes in provocative tests and the nature of occupational work for Phalen's test $(p=0.4132)$ and reverse Phalen's test $(p=0.5898)$.

In the group of people who overused their hands at work, the result of Phalen's test deteriorated by $5.3 \mathrm{~s}$ (in study 1 symptoms appeared after $41.4 \mathrm{~s}$, and in study 2 after only $36 \mathrm{~s}$ ). In the group not overusing their hands, the result was $9.9 \mathrm{~s}$ worse (in study 1 symptoms appeared after $44.8 \mathrm{~s}$, and in study $2-34.9 \mathrm{~s}$ ). In the group of people who overused their hands during work, the result of reverse Phalen's test improved by $0.5 \mathrm{~s}$ (in study 1 symptoms occurred after $41.2 \mathrm{~s}$, and in study 2 after $41.6 \mathrm{~s}$ ). In the group not overusing their hands, the score improved by $3.5 \mathrm{~s}$ (in study 1 symptoms appeared after $39.4 \mathrm{~s}$, while in study 2 after $42.9 \mathrm{~s}$ ).

Hand overuse during occupational work also did not affect the effects of treatment expressed by the change in the electrodiagnostic test parameters (Table 16).

There was no correlation between the obtained changes in the quality of the 2-point sensation test and the nature of occupational work $(\mathrm{p}=0.4684)$.

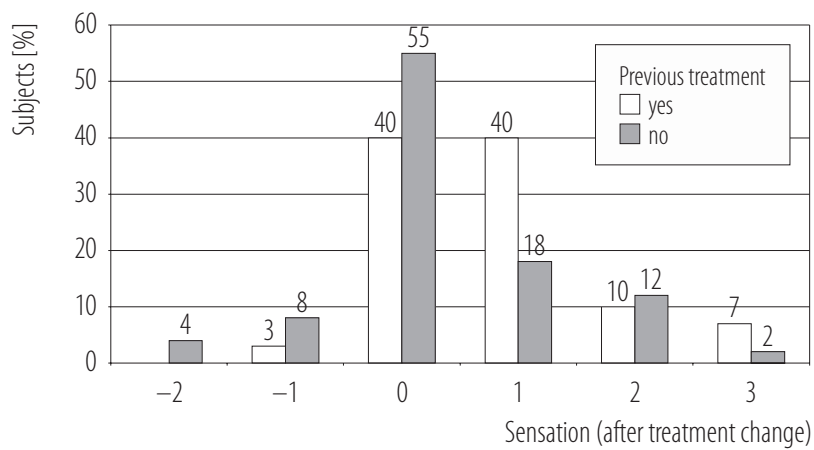

The analysis of 2-point discrimination test results was performed by taking into account the number of levels by which the test result changed. The following types of sensations (according to the American Society for Surgery of the Hand) were distinguished: 1. normal, 2. fair, 3. poor, 4. protective.

Figure 8. Changes in the quality of sensation depending on previous treatment in the study conducted in September 2010 December 2013 in St. Hedvig Provincial Hospital No. 2 in Rzeszów, Poland

\section{DISCUSSION}

The analysis included examinations prior to the therapy (study 1) and 1 year after the end of the therapy (study 2). According to Halac et al., comprehensive physical therapy is also useful in more severe CTS cases when patients report constant day and night symptoms [23]. The results of

Table 16. Changes in electrodiagnostic test parameters depending on the nature of the occupational work performed - the study conducted in September 2010 - December 2013 in St. Hedvig Provincial Hospital No. 2 in Rzeszów, Poland

\begin{tabular}{|c|c|c|c|}
\hline \multirow{2}{*}{$\begin{array}{l}\text { Electrodiagnostic test parameter } \\
\text { (treatment effect) }\end{array}$} & \multicolumn{2}{|c|}{$\begin{array}{l}\text { Occupational hand overuse } \\
\text { (M }(95 \% \mathrm{CI}))\end{array}$} & \multirow{2}{*}{$\mathrm{p}^{\mathrm{a}}$} \\
\hline & $\begin{array}{c}\text { yes } \\
(\mathrm{N}=68)\end{array}$ & $\begin{array}{c}\text { no } \\
(\mathrm{N}=16)\end{array}$ & \\
\hline Distal motor latency (DML) [ms] & $-0.35(-0.62-(-0.09))$ & $-0.16(-0.49-0.18)$ & 0.2696 \\
\hline $\begin{array}{l}\text { Compound muscle action potential } \\
\text { (CMAP) [mV] }\end{array}$ & $0.44(0.10-0.78)$ & $0.19(-0.72-1.09)$ & 0.6970 \\
\hline Distal sensory latency (DSL) [ms] & $-0.31(-0.52-(-0.10))$ & $0.01(-0.30-0.32)$ & 0.1825 \\
\hline $\begin{array}{l}\text { Sensory nerve action potential } \\
\text { (SNAP) }[\mu \mathrm{V}]\end{array}$ & $0.37(-0.61-1.36)$ & $0.44(-0.18-1.07)$ & 0.5996 \\
\hline $\begin{array}{l}\text { Sensory conduction velocity } \\
(\mathrm{SCV})[\mathrm{m} / \mathrm{s}]\end{array}$ & $1.95(0.43-3.46)$ & $0.82(-1.04-2.68)$ & 0.4060 \\
\hline
\end{tabular}

${ }^{a}$ Mann-Whitney test. 
some studies and reviews indicate that physical methods only allow a short-time reduction in the severity of clinical symptoms $[24,25]$. Therefore, it seems necessary to conduct further research involving subjects with various CTS grades, including the long-term effects of the therapy.

According to some authors, occupational activity has a lower impact on the development of CTS symptoms than personal risk factors, which means that CTS cannot be perceived as a "classical" occupational disease [26]. In our research, 37 individuals ( $75 \%$ of the respondents) were included in the risk group related to their occupational activity. The research by Szczechowicz et al. [27] included 40 people with CTS, of whom more than a half performed a job which required computer typing, i.e., assuming a particular posture and making repetitive hand movements. It is worth noting that these were patients who required further rehabilitation after carpal tunnel release [27].

Nawrot et al. demonstrated that it was not age, but the duration of neuropathy which had a major influence on the effects of carpal tunnel release [28]. In our research, 1 year after conservative therapy the oldest subjects $(\geq 60)$ reported lower pain level and the incidence of tingling in their hands, in comparison to younger people. The study was attended by people whose duration of symptoms ranged 2-5 years. The respondents often had problems with precise determination of the time of symptoms occurrence, or stated that these symptoms appeared and disappeared periodically.

The research carried out by Maciagg [29] shows that the physical workers constituting the occupational risk group are characterized by insufficient awareness of the dangers of CTS onset. The author emphasizes that it is necessary to raise public awareness of the consequences of nonergonomic performance of occupational activities and improve working postures [29]. The results of research conducted in the automotive industry also confirmed that a suitable approach by an occupational physician, adherence to occupational health and safety rules and preventive measures taken at workplaces reduce the incidence of CTS and decrease the grade of median nerve damage among workers [30]. Spector mentioned more effective use of conservative methods of treatment and the appropriate modification of the nature of work as an integrated approach to long-term CTS-related disability prevention [31]. The results of our research seem to partially confirm this opinion, because a greater improvement in hand function was noted in the group of people using conservative treatment for the second time.

Other authors emphasize the need for the periodic monitoring of work ergonomics among individual occupational groups in order to reduce hand overuse and CTS incidence [32]. Demiryurek and Gündogdu also believe that, in order to limit occupational disabilities related to CTS in the risk groups, research is needed to assess the impact of preventive measures (training on the symptoms, daily working time reductions) on the incidence of CTS [5]. In future studies, it is important to take into account the impact of workplace modification and other activity modification on the effects of the therapy [33].

The group of people included in our research was characterized by a high percentage of subjects with a severe CTS grade who overused their hands during their professional work, and experienced symptoms of a significant severity before the treatment. Despite this, the use of comprehensive physical therapy gave the expected results that lasted at least a year after the end of the treatment. Some doubts may arise from the changes in the results of Phalen's test depending on the initial electrodiagnostic result, as well as changes in the results of reverse Phalen's test depending on gender. It can be assumed that the results of the provocative test consisting in maintaining a strenuous flexion in the radio-carpal joint can be affected by various changes in the musculoskeletal system, not necessarily related to the compression of the median 


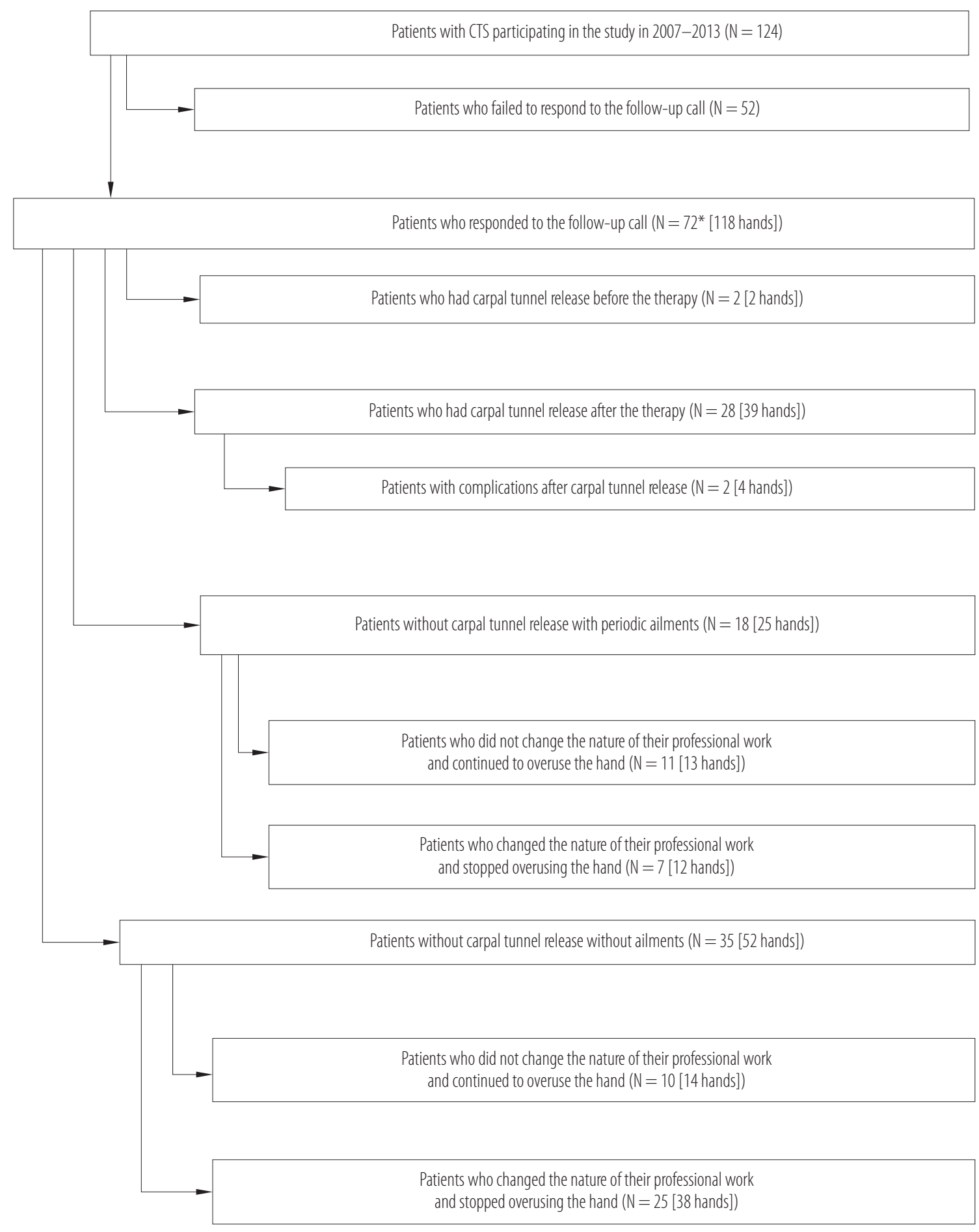

* Eleven patients were counted twice due to the fact that carpal tunnel syndrome (CTS) occurred in both hands and the physiotherapeutic treatments had a different effect.

Figure 9. Flow chart summarizing the number of the subjects at every stage of the study conducted in September 2010 - December 2013 in St. Hedvig Provincial Hospital No. 2 in Rzeszów, Poland 
nerve in the carpal tunnel. The highest ROM in hand joints recorded in the group of the oldest subjects $(\geq 60)$ can be interpreted as the effect of greater involvement in the process of motor rehabilitation (e.g., the continuation of mobilization in the home program) and its better effects. Undoubtedly, the value of the test results would be higher if the number of patients treated and examined 1 year after the end of the treatment was greater. A significant challenge to the study was the fact that if people suffering from CTS do not undergo carpal tunnel release, they participate in various forms of conservative therapy during periods of exacerbation and do not meet the inclusion criterion regarding the non-use, during the period of the study, of any other forms of treatment (including pharmacotherapy).

Additionally, phone contact was made with 77 people who had attended the therapeutic program in the period 2007-2013. The results of the long-term observation, with a follow-up of 5-10 years, showed that out of 118 hands treated conservatively, the state of 77 hands improved so much that these hands did not need to undergo carpal tunnel release. In the group of 35 individuals (52 hands) who did not report any complaints at the time, 10 people (14 hands) had not stopped overusing their hands during their professional work. The remaining 25 individuals ( 38 hands) changed the nature of their work or modified their workplace. In the group of 18 individuals ( 25 hands) who reported only a periodic occurrence of symptoms, 11(13 hands) did not change the nature of their work, while 7 individuals (12 hands) changed or modified the work place and stopped overusing the hand (Figure 9). It is also worth noting that of the 72 individuals who could be contacted after 5-10 years, none refused to provide information about their health status, which can be interpreted as their being fully satisfied with the treatment conducted many years before.

Among the people who were contacted, there were 35 individuals who decided to change their occupation or stop working. The following occupations were represented in the group: farmer (6 individuals), cashier ( 3 individuals), housekeeper (3 individuals), nurse (3 individuals), computer worker (2 individuals), gardener (1 individual), builder ( 2 individuals), physical worker in a laundry service ( 2 individuals), pastry shop employee slicing cakes (2 individuals), electrician (2 individuals), carpenter (1 individual), tailor (1 individual), warehouse worker (1individual), hairdresser(1individual), vehiclecovermaker (1 individual), wedding bouquet maker (1 individual), wicker basket maker (1 individual), money counter (1 individual), butcher (1 individual).

\section{CONCLUSIONS}

The effects 1 year after the end of conservative treatment in patients with CTS, expressed by a reduction in the severity and frequency of subjective symptoms, are independent of the patient's age.

The effects 1 year after the end of conservative treatment in patients with CTS, expressed by an improved electroneurography score, may be worse in the elderly.

The long-term effects of conservative treatment in patients with CTS, expressed by a reduction in subjective symptoms, are less favorable in individuals with a worse initial electrodiagnostic test result.

The repeated implementation of conservative treatment in patients with CTS gives better results, expressed by the resolution of subjective symptoms and vegetative disorders, as well as hand function improvement, in comparison with the first-time treatment.

Hand overuse during work has a negative influence on the effects of conservative treatment of individuals with CTS, expressed by pain reduction and other subjective day and nighttime symptoms, as well as vegetative disorders.

Changing the nature of work or modifying the workplace have a positive effect on the long-term maintenance of the effects of conservative treatment in individuals with CTS. 


\section{REFERENCES}

1. Manfield L, Thomas M, Lee SW. Flexoor pollicis longus tenosynovitis in patients with carpal tunnel syndrome. Am J Phys Med Rehabil. 2014;93(6):524-7, https://doi.org/10.1097/PHM. 0000000000000010 .

2. Lewis C, Mauffrey C, Newman S, Lambert A, Hull P. Current concepts in carpal tunnel syndrome: A review of the literature. Eur J Orthop Surg Traumatol. 2010;20(6):445-52, https://doi.org/10.1007/s00590-010-0585-9.

3. Newington L, Harris EC, Walker-Bone K. Carpal tunnel syndrome and work. Best Pract Res Clin Rheumatol. 2015; 29(3):440-53, https://doi.org/10.1016/j.berh.2015.04.026.

4. Kluger N. National survey of health in the tattoo industry: Observational study of 448 French tattooists. Int J Occup Med Environ Health. 2017;30(1):111-20, https://doi.org/10.13075/ ijomeh.1896.00634.

5. Demiryurek BE, Aksoy Gündogdu A. Prevalence of carpal tunnel syndrome and its correlation with pain amongst female hairdressers. Int J Occup Med Environ Health. 2018;31(3): 333-9, https://doi.org/10.13075/ijomeh.1896.01068.

6. Harris-Adamson C, Eisen EA, Kapellusch J, Garg A, Hegmann KT, Thiese MS, et al. Biomechanical risk factors for carpal tunnel syndrome: A pooled study of 2474 workers. Occup Environ Med. 2015;72(1):33-41, https://doi.org/10.1136/ oemed-2014-102378.

7. Palmer KT, Harris EC, Coggon D. Carpal tunnel syndrome and its relation to occupation: A systematic literature review. Occup Med. 2007;57(1):57-66, https://doi.org/10.1093/ occmed/kql125.

8. Thomsen JF, Gerr F, Atroshi I. Carpal tunnel syndrome and the use of computer mouse and keyboard: A systematic review. BMC Musculoskelet Disord. 2008;9:134, https://doi. org/10.1186/1471-2474-9-134.

9. Mediouni Z, de Roquemaurel A, Dumontier C, Becour B, Garrabe H, Roquelaure Y, et al. Is carpal tunnel syndrome related to computer exposure at work? A review and metaanalysis. J Occup Environ Med. 2014;56(2):204-8, https://doi. org/10.1097/JOM.0000000000000080.
10. Van Rijn RM, Huisstede BM, Koes BW, Burdorf A. Associations between work-related factors and the carpal tunnel syndrome - A systematic review. Scand J Work Environ Health. 2009;35(1):19-36, https://doi.org/10.5271/sjweh.1306.

11. Pullopdissakul S, Ekpanyaskul C, Taptagaporn S, Bundhukul A, Thepchatri A. Upper extremities musculoskeletal disorders: Prevalence and associated ergonomic factors in an electronic assembly factory. Int J Occup Med Environ Health. 2013;26(5):751-61, https://doi.org/10.2478/s13382013-0150-y.

12. Wipperman J, Goerl K, Carpal tunnel syndrome: Diagnosis and management. Am Fam Physician. 2016;94(12):993-9.

13. Kouyoumdjian JA, Zanetta DM, Morita MP. Evaluation of age, body mass index, and wrist index as risk factors for carpal tunnel syndrome severity. Muscle Nerve. 2002;25(1):937, https://doi.org/10.1002/mus.10007.

14. Zwolińska J, Kwolek A., [Effectiveness of physiotherapeutic treatment of patients with carpal tunnel syndrome (CTS)]. Med J Rzeszow Univ Nat Med Inst. 2012;10(4):428-45. Polish.

15. Katz JN, Keller RB, Fossel AH, Punnett L, Bessette L, Simmons BP, et al. Predictors of return to work following carpal tunnel release. Am J Ind Med. 1997;31(1):85-91.

16. Demidaś A, Ratajczak B, Pisula-Lewandowska A. The influence of the hydro-massage on the sense of touch in the upper extremities. Acta Biooptica et Inf Med. 2010;16(3):212-4.

17. Page MJ, O'Connor D, Pitt V, Massy-Westropp N. Therapeutic ultrasound for carpal tunnel syndrome. Cochrane Database Syst Rev. 2013;28(3):CD009601, https://doi.org/ 10.1002/14651858.CD009601.pub2.

18. Oskouei AE, Talebi GA, Shakouri SK, Ghabili K. Effects of neuromobilization maneuver on clinical and electrophysiological measures of patients with carpal tunnel syndrome. J Phys Ther Sci. 2014;26(7):1017-22, https://doi.org/10.1589/ jpts.26.1017.

19. Page MJ, O'Connor D, Pitt V, Massy-Westropp N. Exercise and mobilization interventions for carpal tunnel syndrome. Cochrane Database Syst Rev. 2012;13(6):CD009899, https:// doi.org/10.1002/14651858.CD009899. 
20. Wilson JK, Sevier TL. A review of treatment for carpal tunnel syndrome. Disabil Rehabil. 2003;25(3):113-9, https://doi. org/10.1080/0963828021000007978.

21. Kwolek A, Drużbicki M, Bieniasz W, Zwolińska J, Przysada G. [Hand examination position - possible use in rehabilitation]. Postępy Rehabil. 2011;25(1):23-8. Polish.

22. Chmielewska D, Skęczek-Urbaniak A, Kubacki J, Błaszczak E, Kwaśna K. Effectiveness of carpal tunnel syndrome rehabilitation after endoscopic versus open surgical release. Ortop Traumatol Rehabil. 2013;15(5):417-27, https://doi.org/ $10.5604 / 15093492.1084354$.

23. Halac G, Demir S, Yucel H, Niftaliyev E, Kocaman G, Duruyen $\mathrm{H}$, et al. Splinting is effective for night-only symptomatic carpal tunnel syndrome patients. J Phys Ther Sci. 2015;27(4):993-6, https://doi.org/10.1589/jpts.27.993.

24. Yildiza N, Atalaya NS, Gungen GO, Sanal E, Akkayaa N, Topuza O. Comparison of ultrasound and ketoprofen phonophoresis in the treatment of carpal tunnel syndrome. J Back Musculoskelet Rehabil. 2011;24(1):39-47, https://doi. org/10.3233/BMR-2011-0273.

25. Huisstede BM, Hoogvliet P, Randsdorp MS, Glerum S, van Middelkoop M, Koes BW. Carpal tunnel syndrome. Part I: Effectiveness of nonsurgical treatments - A systematic review. Arch Phys Med Rehabil. 2010;91(7):981-1004, https://doi.org/10.1016/j.apmr.2010.03.022.

26. Riccó M, Cattani S, Signorelli C. Personal risk factors for carpal tunnel syndrome in female visual display unit workers. Int J Occup Med Environ Health. 2016;29(6):927-36, https://doi.org/10.13075/ijomeh.1896.00781.
27. Szczechowicz J, Pieniążek M, Pelczar-Pieniążek M. Restoration of hand function and ability to perform activities of daily living following surgery for carpal tunnel syndrome. Ortop Traumatol Rehabil. 2008;10(2):152-67.

28. Nawrot P, Nowakowski A, Bartochowski Ł, Jaroszewski J. [Influence of patient's age and duration of neuropathy on the results of surgical management of compression neuropathies in the upper limb]. Chir Narządów Ruchu Ortop Pol. 2008;73(2):116-28. Polish.

29. Maciag L. [The awareness of the possibility of the carpal tunnel syndrome occurrence in the people from the professional risk group]. Przegl Med Uniw Rzesz Inst Leków. 2010;8(3):289-97. Polish.

30. Žídková V, Nakládalová M, Zapletalová J, Nakládal Z, Kollárová $H$. Experiences with preventing carpal tunnel syndrome in an automotive plant. Int J Occup Med Environ Health. 2017;30(1):45-54, https://doi.org/10.13075/ijomeh. 1896.00793 .

31. Spector JT, Turner JA, Fulton-Kehoe D, Franklin G. Presurgery disability compensation predicts long-term disability among workers with carpal tunnel syndrome. Am J Ind Med. 2012;55(9):816-32, https://doi.org/10.1002/ajim.22029.

32. Chiang CL, Liao CY, Kuo HW. Postures of upper extremity correlated with carpal tunnel syndrome (CTS). Int J Occup Med Environ Health. 2017;30(2):281-90, https://doi. org/10.13075/ijomeh.1896.00566.

33. Graham B. Nonsurgical treatment of carpal tunnel syndrome. J Hand Surg. 2009;34(3):531-4, https://doi.org/10. 1016/j.jhsa.2009.01.010.

This work is available in Open Access model and licensed under a Creative Commons Attribution-NonCommercial 3.0 Poland License - http://creativecommons.org/ licenses/by-nc/3.0/pl/deed.en. 